\section{New Labour: Not So New Prospects for British Higher Education}

\section{Michael Shattock}

Michael Shattock is registrar of the University of Warwick, and editor of Minerva. Address: Registry, University of Warwick, Coventry, CV4 7AL, UK. Fax: <44-1203-524578>.

W hen a prospective prime minister defines his party's priorities as "education, education, education," he can be sure of capturing the attention of the higher education community, even though it recognizes that he may be more interested in the mass of compulsory, rather than the relative elite of postcompulsory, education. In Britain, where government recurrent grants to universities fell by 45 percent per student-place over the previous 15 years and where a National Inquiry into Higher Education (the Dearing Committee) was established by the Conservative government, with Labour Party support, to report in July 1997, just three months after the new government had taken office, expectation was raised to unrealistic heights. Nine months later the government's response to the Dearing Report and its consultative paper, with the overblown title: The Learning Age: A Renaissance for a New Britain, have proved to be a severe disappointment. The government continues to hold out hope for the results of its Comprehensive Spending Review - to be carried out between May and July-but the higher education community is beginning to face up to the fact that very much less has changed than it had hoped for.

In the past decade the British university system has been transformed.

In the past decade the British university system has been transformed. In 1988 the polytechnics were removed from local authority control and-as the political left described it- "nationalized" under a Polytechnics and Colleges Funding Council (PCFC) while the University Grants Committee (UGC) was abolished and replaced by a lay-dominated Universities Funding Council (UFC), which had been told it had no role in planning the university system but merely the task of funding the universities on a formula basis for student numbers and on a selective basis for research.
Both Funding Councils adopted a market-oriented model that encouraged a rapid expansion of students at marginal costs, and between 1988 and 1995 numbers rose by 50 percent. In 1992 the polytechnics and some colleges were given university status and-in a further burst of administrative reorganization - the two Funding Councils were abolished and new Funding Councils for England, Wales, and Scotland were created. This had the twin effects of removing the "binary line," or distinction in mission between universities and polytechnics, and breaking up the unified approach to the funding of British universities that had been in force since the end of the First World War. The isolation of Scotland and Wales was not total, however, because the research assessment exercise (RAE) a peer group assessment of the quality of research, discipline by discipline, remained a unified exercise. The selective resource allocation models adopted by the Funding Councils differed slightly, but the league tables resulting from the assessment scores were compiled on a national rather than a regional basis.

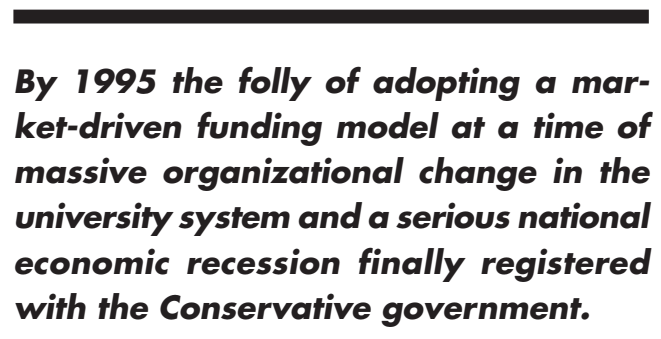

By 1995 the folly of adopting a market-driven funding model at a time of massive organizational change in the university system and a serious national economic recession finally registered with the Conservative government. The expansion of student numbers was brought sharply to a halt, the open-ended funding model was abandoned, and an instruction was issued to universities that they would be "fined" if they overshot the target numbers adopted by the Funding Councils and subjected to financial "claw back" if they undershot them. But the rapid uncontrolled expansion had brought considerable changes in the balance of the system. Many of the "old," or pre-1992 universities, had resisted lowering their entrance levels and had expanded only slowly in the 1988-95 period, while several of the "new," post-1992, universities had grown from around 10,000 to 20,000 or even 25,000 students following largely nonselective entrance policies. Student/staff ratios in many of these universities had fallen to 1:20 or 1:25 as compared to 1:12 before the period of rapid growth. Meanwhile the RAE, which included the post-1992 universities in 1992 
for the first time, had continued the process of creating a hierarchy of research-intensive universities, although the 4 RAEs $(1986,1989,1992$, and 1996) tended to confirm a group of universities as forming a kind of top 10: Cambridge, Oxford, LSE, Imperial College, University College, London. Warwick, Edinburgh, York, and UMIST. None of the post-1992 universities have yet overtaken any of the "old" universities in the research league tables, but the substantial resources geared to student numbers going to the largest of the new universities like Sheffield Hallam, Manchester Metropolitan University, Leeds Metropolitan University, De Montfort University, or Middlesex University enable them to head-hunt research-active faculty from the "old" universities in the hope that their publication records will earn them RAE success and additional funding. The RAE, which has been subject to scrupulous peer review, has in general benefited research by encouraging a greater concentration in fewer institutions. However, it has also encouraged "mission drift" among the "new" universities and has sparked off a rise in salaries at the upper end of the faculty market as universities compete to gain departments higher grades in the RAE, thus widening the salaries band at a time when university salaries as a whole have remained depressed.

\section{Over the last decade a number of uni- versities have turned vigorously to pri- vate fundraising.}

The developments of the last decade have not, however, been wholly bad. The proportion of young people entering higher education has risen from just under 20 percent to over 32 percent, although the participation by young people from the lowest social classes has changed hardly at all. In research, the RAE and the reorganization of medical education in London have reinforced the position of Cambridge, Oxford, University College, London, and Imperial College, as major institutions, and have encouraged the recognition of Warwick and York Universities, founded in the 1960s, as significant research universities. Concern about the dangers of a decline in teaching quality arising from the expansion and the prioritizing of research to benefit from the RAE has led the Funding Councils to set up a Teaching Quality Assessment program that has had the effect of giving teaching a higher profile in universities. Unfortunately, it has also added greatly to the bureaucratic demands placed on academic departments and on the university system as a whole. Recent analyses suggest that the most successful research universities also come out at the top of the teaching league tables. A decade of league tables has created an elite group of universities-the so-called Russell Group (because they meet in the Russell Hotel in London) - but has also led to the formation of the Coalition of Modern Universities, a group of "new" universities concerned to defend themselves against press accusations that standards have been lowered among the former polytechnics.

\section{The university system as a whole is moving into deficit.}

The primary concern that led to the establishment of the Dearing Committee was to address the financial difficulties in higher education at a time when the Conservative government was imposing cuts of 3 percent per annum on university funding. The simple fact was that, as in the rest of Europe, the state could not pay for the mass higher education system it had created. The new government, however, while accepting Dearing's recommendation that students should pay $£ 1000$ fees, imposed a means test that will mean that about onethird will pay no fees, one-third about half fees, and only one-third full fees. It also decided, against Dearing's advice, to phase out student maintenance grants, already severely reduced by the Conservatives, and encourage students to rely entirely on a government-supported loan scheme. This has produced predictable criticism from the student body. While the government has improved the universities' financial position slightly in the last year, it has significantly failed to match what universities were expecting. Over the last decade a number of universities have turned vigorously to private fundraising, but, inevitably, age, tradition, academic success, and well-heeled alumni have meant that the two richest universities, Oxford and Cambridge, have become richer while the "new" universities, without any such advantages, have become poorer.

Nine months into a new Labour government some British universities remain strong-at least stronger than they were a decade ago; but the university system as a whole is moving into deficit; and as institutional differentiation increases there are public doubts about academic process and quality at the lower end of the hierarchy. With all universities dependent to a greater or lesser extent on overseas students as a source of income, these doubts are beginning to have a self-reinforcing impact on some universities' income. There is a feeling about that even greater changes must be in the wind. 